Yayınlayan: Ankara Üniversitesi KASAUM

Adres: Kadın Sorunları Araştırma ve Uygulama Merkezi, Cebeci 06590 Ankara

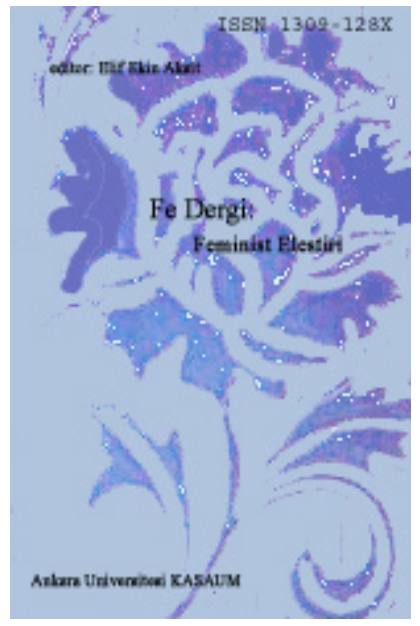

Fe Dergi: Feminist Eleștiri 12, Sayı 1

Erişim bilgileri, makale sunumu ve ayrıntılar için:

http://cins.ankara.edu.tr/

Hong Kong'da Yaşayan Filipinli Ev İşi ve Bakım

Çalışanlart ile Kadın İşverenlerin Annelik Deneyimleri

Deniz Kemik

Çevrimiçi yayına başlama tarihi: 1 Haziran 2020

Yazı Gönderim Tarihi: 16.4.2019

Yazı Kabul Tarihi: 19.05.2020

Bu makaleyi alıntılamak için: Deniz Kemik, "Hong Kong’da Yaşayan Filipinli Ev İşi ve Bakım Çalışanları ile Kadın İşverenlerin Annelik Deneyimleri.” Fe Dergi 12, no. 1 (2020), 82-95.

URL: http://cins.ankara.edu.tr/23_7.pdf

$\mathrm{Bu}$ eser akademik faaliyetlerde ve referans verilerek kullanılabilir. Hiçbir şekilde izin alınmaksızın çoğaltılamaz. 


\title{
Hong Kong'da Yaşayan Filipinli Ev İşi ve Bakım Çalışanları ile Kadın İşverenlerin Annelik Deneyimleri Deniz Kemik*
}

\begin{abstract}
Bu makale, Hong Kong'da yaşayan Filipinli ev işi ve bakım çalışanlarının ve kadın işverenlerin annelik deneyimlerini anlamayı amaçlar ve bu deneyimlerin sınıf, etnisite ve göç politikaları kesişiminde nasıl farklılaşı̆̆ğnı tartışır. Bu amaçla feminist duruş noktası epistemolojisinden yararlanılarak niteliksel bir araştırma yürütülmüştür. Araştırmada onsekiz Filipinli işçi ve onsekiz kadın işveren ile derinlemesine görüşmeler yapılmış ve her iki gruptan beşer kadının katılımıyla dört odak grup görüşmesi düzenlenmiştir. Araştırmanın bulgularına göre Filipinli ev işi ve bakım çalışanlarının ve kadın işverenlerin "iyi anneliği”" sınıfsal konumları, etnik kökenleri ve göç deneyimleri çerçevesinde farklı tanımladıkları ortaya çıkmıştır. Filipinli yardımcıların annelik deneyimlerini çocuklarından ayrı yaşıyor olmaları, Hong Kong'un göç politikaları ve işverenleriyle kurdukları ilişkiler dönüşürü̈rken; kadın işverenlerin annelik deneyimlerini ise Hong Kong'daki rekabetçi çocuk yetiştirme pratikleri, eğitime verilen önem ve göçmen yardımcılarından aldıkları desteğin şekillendirdiği gözlemlenmiştir.
\end{abstract}

Anahtar Kelimeler:Annelik, ev işi ve bakım emeği, sınıf, etnisite, Hong Kong

\section{The Mothering Experiences of Filipina Domestic Workers and Female Employers Living in Hong Kong}

This article aims to understand the mothering experiences of Filipina domestic and care workers and female employers in Hong Kong. It also discusses how mothering experiences differentiate at the intersection of class, ethnicity and migration policies. In line with this objective qualitative research was conducted by using feminist standpoint epistemology. In the research, in-depth interviews were carried out with eighteen Filipina workers and eighteen female employers and four focus group meetings were organised with the participation of five women from each group. According to the findings of the research, based on their class, ethnicity and migration experiences, Filipina domestic and care workers and female employers define "good mothering" differently. The mothering experiences of Filipina workers are transformed by the separation from their children (as they live apart), the migration policies of Hong Kong and the relationship with their female employers. The mothering experiences of female employers are shaped by the competitive childrearing practices in Hong Kong, the importance given to the education and the support they receive from their migrant helpers.

Keywords:Mothering, domestic and care work, class, ethnicity, Hong Kong

\section{Giriş}

Çocuklarına daha iyi bir gelecek sağlamak için göç eden Filipinli ev işi ve bakım çalışanları uzaktan anneliği deneyimlerken, onları istihdam eden kadın işverenler ev işi ve bakım alanında aldıkları destek sayesinde çocuklarına yoğun annelik yapabilirler. Göç etme ve göçmen yardımcı istihdam etme her iki kadının da annelik deneyimlerini tamamen değiştirir. Bu araştırmada küresel bir şehir olan Hong Kong'da yaşayan göçmen ev işi ve bakım çalışanlarının ve kadın işverenlerin annelik deneyimlerini farklı annelik ideolojilerinin etkisiyle nasıl inşa ettiklerini, bu deneyimlerin sınıf, etnisite ve göç politikaları kesişiminde nasıl farklılaştığını ortaya koymaya çalışıyorum. Bu karşılaştırmanın amacı göç eden Filipinli kadınların, ülke değiştiren expat kadınların ve ülke

\footnotetext{
*Ankara Üniversitesi Toplumsal Cinsiyet ve Kadın Çalı̧̧maları Bölümü Doktora Öğr. denizkemik@gmail.com https://orcid.org/0000-00032023-8764 Yazının Gönderim Tarihi: 16.04.2020, Yazının Kabul Tarihi: 19.05.2020

Yazar, araştırması için TÜBİTAK tarafından 2214-A Yurt Dışı Doktora Sırası Araştırma Burs Programı çerçevesinde desteklenmiştir.
} 
değiştirmeyen Çinli kadınların dönüşen annelik deneyimlerini daha iyi anlamamızı sağlamasıdır. Göçmen kadınlardan farklı koşullarda da olsa expat kadınların da annelikleri ülke değiştirdikleri için dönüşür. Özellikle göçmen ve expat kadınlara şehirde sunulan imkanlara bakıldığında sınıf ve etnisitenin, göç politikalarının belirlenmesinde ve annelik deneyimlerinin şekillenmesinde ne kadar etkili olduğu ortaya çıkmaktadır.

Kadınlar arasındaki eşitsizliklerin bakım emeğinin metalaşması ve annelik deneyimlerinin farklılaşması üzerinden yeniden üretildiği varsayımı ile yola çıkıyorum. Literatürde göçmen kadınların işverenleriyle olan ilişkileri bakım emeğinin metalaşması, tahakküm ve sınıf ilişkileri açısından ele alınmış olsa da her iki gruptan kadının annelik deneyimlerine odaklanılan çalışma sayıca azdır (Yeoh ve Huang, 2010; Cheng, 2006 ${ }^{\text {). Bu }}$ nedenle, bu çalışma farklı sınıf ve etnisiteden olan hem Filipinli göçmen kadınların hem de Çinli ve expat ${ }^{2}$ kadın işverenlerin annelik deneyimlerini ilişkisel olarak incelemeye çalışarak farklılaşır. ${ }^{3}$ Makalede önce annelik ve bakım emeği literatürlerine değinerek kuramsal ve metodolojik çerçeveyi çizeceğim; küresel bir şehir olarak Hong Kong'daki bağlamı kısaca ele alacağım. Daha sonra Filipinli yardımcıların annelik deneyimlerini anlamak için "iyi anne" olma anlayışlarına ve çocuklarına uzaktan annelik yapmayı nasıl gördüklerine odaklanacağım. Daha sonra Filipinli yardımcı ${ }^{4}$ istihdam eden kadın işverenlerin annelik deneyimlerini anlamak için benzer şekilde "iyi anne" olma anlayışlarına bakacağım. Son olarak da her iki grubun annelik deneyimlerinin sınıf, etnisite ve göç politikaları çerçevesinde nasıl farklılaştığını ve ilişkisel olduğunu ele alarak bu makaleyi noktalayacağım.

\section{Kuramsal ve Metodolojik Çerçeve}

Modern toplumlarda cinsiyete dayalı biyolojik ve ideolojik farklılıklar iç içe geçmiştir; oysa toplumsal eşitsizliklere neden olan ve biyolojik özelliklerden kaynaklandığı düşünülen ve biyolojik değişmezlik yaklaşımından alınan destek ile meşrulaştırılan toplumsal farklılıklar; aslında ideolojiktir (Sancar 2012, 24). Benzer şekilde toplumlarda kadınlar doğum yapabildikleri için anneliğin de biyolojik olduğu düşünülür, aslında toplumda kadına atfedilen annelik rolü biyolojik değil ideolojiktir (Glenn 1994, 3). Annelik, tarih üstü bir kavram gibi ele alınsa da aslında annelik rolü de anneliğin anlamı da tarihsel ve ideolojik olarak değişir. Özcü annelik ideolojisi, anneliği kadın için doğal, evrensel ve içgüdüsel olarak görür; anneliğin değişmez ve kaçınılmaz olduğunu öne sürer, kadınlığı da annelik üzerinden tanımlar (DiQuinzio 2007, 547). Toplumsal inşacı ideoloji ise anneliği, kadınların biyolojik özelliklerine indirgemez, toplumsal olarak inşa edilmiş bir kavram olarak ele alır yani annelik ideolojiktir; annelik deneyimleri de tarihsel ve toplumsal olarak farklılıklar gösterir (Glenn 1994, 3).

Tarih boyunca toplumsal değişimler ile birlikte annelik ideolojilerinin değiştiğini görüyoruz. Badinter $(2011,119)$ her kültüre ve tarihsel döneme göre toplumların benimsediği ideal annelik modelinin değiştiğini öne sürer; kadınların önünde ise üç seçenek vardır bu modeli benimsemek, reddetmek ya da müzakere etmek.

Anneliğin "sevgi emeği” olarak kutsallaştırılması, kadınlara özgü, doğal bir içgüdü olarak görülmesi ve bir görev olarak kadınlara atfedilmesi toplumdaki iktidar ilişkilerini gizler. Oysa annelik, toplumdaki tahakküm ilişkilerinin, toplumsal cinsiyet, sınıf ve etnisiteye dayalı tüm eşitsizliklerin yeniden üretildiği bir alandır. Her ne kadar özel alana ait gibi görülse de nasıl bakım emeği politik bir alansa (Cox 2010, 113) annelik emeği de politiktir ve hiçbir zaman siyasi mücadeleden kaçamaz.

Annelik tarih boyunca hem feminist kuram hem de feminist siyaset için ikircikli bir mesele olmuştur. 1960'larda ve 1970'lerin başında 2. Dalga Feminist kuramcılar anneliği kadınların toplumsal olarak ikincil konumda olmasına ve ezilmesine neden olan ve kadınların eşitlik mücadelesi önünde engel teşkil eden bir kurum olarak değerlendirmişlerdir. 1980'lerde ise yine 2. Dalga Feminist kuramcılardan kültürel feministler, kadınların geleneksel kültürü, pratiği ve deneyimleriyle bir feminist siyasal etiğin oluşturulabileceğini öne sürmüşlerdir (Donovan 1997, 319). Kültürel feminizmden beslenen anacı (maternal) feminizm ise (Sarah Ruddick, 1980; Carol Gilligan, 1982) kadınlar tarafından özel alanda yapılan bakım işine daha fazla değer atfedilmesi, annelik yoluyla edinilen doyurma, özen, şefkat gibi anaç değerlerin kamusal yaşama yansıtılmasını savunmuştur.

Rich $(1976,13)$ "Of Women Born” adlı eserinde anneliği "kadının kendi üreme gücüyle ve çocuklarıyla kurduğu potansiyel ilişkiler ve bu potansiyelin ve tüm kadınların erkek kontrolünde kalmasını sağlayacak kurum olarak ikiye ayırır"5. Annelik kurumu (motherhood) patriyarkal düzen adına kadınların davranışlarını düzenler, kısıtlar ve kadınlar üzerinde baskı kurarken annelik deneyimleri (mothering) kadınlar tarafından tanımlandığı, kadın merkezli olduğu için kadınları güçlendirir (O’Reilly 2007, 794). Ancak ne annelik kurumu sabit bir patriyarkal annelik ideolojisiyle düzenlenir ne de annelik deneyimleri tüm kadınlar için gerçek bir güçlenme 
sağlar. Zira, kadınların toplumdaki farklı konumları annelik kurumundan nasıl etkileneceklerini ve anneliği nasıl deneyimleyeceklerini şekillendirir.

Siyahi feminist düşüncenin öncü ismi Patricia Hill Collins (1994, 62), feminist annelik kuramlarını kısmi bir bakış açısına sahip oldukları ve beyaz, orta sınıf kadınların deneyimlerini evrensel olarak ele aldıkları için eleştirir. Collins (1994), anneliğin toplumsal cinsiyet, ırk ve sınıfın kesişiminde deneyimlendiğinin altını çizer (45) ve renkli kadınların annelik deneyimlerinin dikkate alınmasının bu kuramları zenginleştireceğini belirtir (49). Crenshaw $(1991,1244)$ da siyahi kadınların deneyimlerinin toplumsal cinsiyet, sınıf ve ırk gibi tahakküm eksenlerinin kesişiminde ele alınması gerektiğini dile getirir; feminist ve ırkçılık karşıtlı̆̆ı literatürlerde bu deneyimlere yeterince yer verilmediğini öne sürer (1242). Post-kolonyal teori, siyahi feminizm ve queer teoriden gelen eleştiriler ile feminist kuramda da kadınların farklı konumlarının ve deneyimlerinin olduğu ortaya konmuş, deneyimi, ırk/etnisite, sınıf, toplumsal cinsiyet ve cinsel yönelim gibi farklılıkları ele alan kesişimsel/ilişkisel yaklaşımlar gündeme gelmiştir.

Anthias $(2012,130)$ toplumdaki konumlarımızın hiyerarşik ilişkilere gömülü olduğunu ileri sürer. $\mathrm{Bu}$ makalede toplumsal konum kavramı ile bireylerin toplumsal cinsiyet, etnik köken ve ait oldukları sınıfa göre toplumdaki hiyerarşik tahakküm ilişkilerinde farklı yerlere yerleştirilmelerinden söz ediyorum. Bourdieu (1986, 16) sınıf kuramında sermayeyi ekonomik, kültürel sermaye ve toplumsal olarak üçe ayırır. Sınıf, insanların hiyerarşiler üreten gündelik yaşam pratiklerini ifade eder (Anthias 2012, 123). Beğeniler ve yaşam tarzları da sınıfsal ayrımların kendilerini gösterdikleri pratiklerdir (Bourdieu 1984, 2). Makalede farklı annelik deneyimlerinin üretilmesinde sınıfın etkisini bu çerçevede ele alıyorum ve kadın işverenlerin Filipinli ev işi ve bakım çalışanlarına kıyasla ekonomik, kültürel ve toplumsal kaynaklara erişimlerinin daha fazla olması nedeniyle anneliği farklı deneyimlediklerini öne sürüyorum. Öte yandan sadece sınıfsal farklılıkların değil etnik köken ve göç politikalarının uygulanmasına ilişkin farklılıkların da annelik deneyimlerinin oluşmasında etkili olduğunu ortaya koyuyorum.

"Deneyim etnik, sınıflanmış ve cinsiyetlenmiş kadının üretiminde, öznelliğinin üretiminde kilit bir rol oynar" (Skeggs 1997, 38); ancak deneyimler saf dolaysız bilgi ve gerçeklikler değildir. Konumlanmış öznelerin konumlanmış bakış açılarından aktarılırlar yani bütün deneyimler bir pratik, söylem ve yorumlama sürecinden geçer (28). Skeggs'e (1997) göre özneler olarak deneyimlerimiz aracılığıyla ve onların zaman içerisinde yorumlanması ile üretiliriz. Scott $(1991,779)$ da bireylerin deneyime sahip olmadığını aksine öznelerin deneyim aracılığıyla kurulduğunu öne sürer ona göre de deneyim her zaman yorumlamaya ihtiyaç duyar.

Kadın deneyimi de hem feminist kuramda hem de feminist siyasette önemli bir yere sahip olmuştur. Nancy Hartsock, Dorothy Smith, Sandra Harding ve Donna Harraway gibi kuramcılar kadınların yaşadıkları farklı deneyimler sonucu farklı bir kadın bakış açısı geliştirdikleri için gündelik deneyimleri sosyal bilim araştırmalarında başlangıç noktası olarak almayı öne sürmüşler ve feminist duruş noktası epistemolojisi oluşturmuşlardır. Harding $(2004,6)$ de farklı toplumsal konumlardan kadınların deneyimlerinin, hayatlarının ve faaliyetlerinin nitel araştırmanın salt bilgi kaynağı olmasa da başlangıç noktası olarak alınabileceğini öne sürer.

Bu makale doktora tez çalışmam için yürüttüğüm nitel araştırmanın bazı sonuçlarını ortaya koyar. Araştırmada Hong Kong'da Filipinli ev işi ve bakım çalışanlarının ve Filipinli yardımcı istihdam eden kadın işverenlerin annelik deneyimlerinin nasıl inşa edildiğini anlamak için feminist duruş noktası epistemolojisinden yararlanarak nitel araştırma yürüttüm. Örneklemi kartopu örnekleme ve amaçsal örnekleme yöntemiyle oluşturdum. Mayıs 2018- Aralık 2019 arasında gerçekleştirdiğim veri toplama sürecinde on sekiz Filipinli ev işi ve bakım çalışanı ve on sekiz kadın işveren olmak üzere toplam otuz altı anne ile derinlemesine görüşmeler yaptım; her iki gruptan beşer kadının katıldığı dört odak grup görüşmesi düzenledim.

Görüştüğüm Filipinli kadınlar 31-48 yaş aralığında olup ortalama iki çocukları vardır ve çocukları da 421 yaş aralığındadır. Filipinli kadınlar ortalama yedi buçuk yıldır Hong Kong'da yaşamakta, tümü hem ev işi yapmakta hem de çocuk bakmaktadır. Kadın işverenler de 29-46 yaş aralığında olup, ortalama iki çocukları vardır. Çocukları da 5 aylık-15 yaş aralığındadır. Görüşülen on sekiz kadın işverenin on biri Çinli ve yedisi expattır; expat olan kadınlar eşlerinin işi nedeniyle Hong Kong'a taşınmışlardır. On ikisi çalışmakta ve altısı çalışmamaktadır. Çalışan kadınlar ise bankacılık, sigortacılık, insan kaynakları ve eğitim sektörlerinde çalışmaktadırlar. Sadece bir tanesi eşinden ayrılmıştır. Örneklemdeki Filipinli ev işi ve bakım çalışanları ile kadın işverenler arasında iş ilişkisi bulunmamaktadır. Bir Filipinli yardımcı hariç tamamı işverenleriyle birlikte yaşamaktadır. Bir derinlemesine görüşme ${ }^{7}$ hariç tüm görüşmeleri İngilizce olarak yaptım ve katılımcıların anlatılarından seçtiğim alıntıları Türkçe'ye çevirdim. Toplanan verileri tematik olarak analiz ettim ve her iki gruptaki kadınların anlatılarından annelik deneyimlerine dair örüntüler ortaya çıkarttım. 


\section{Göç ve Bakım Emĕğinin Metalaşmast}

1990’larda küreselleşmenin etkisiyle neo-liberal ekonomik politikalar ekonomik açıdan az gelişmiş Üçüncü Dünya Ülkelerinden Asyalı ve Latin Amerikalı kadınlar, ekonomik olarak gelişmiş Birinci Dünya Ülkelerine ev hizmetlerinde çalışmak ve çocuk bakmak üzere göç etmeye başlamışlardır. Küresel Güney’deki kadınların ülkelerinde bulamadıkları iş fırsatlarını Küresel Kuzey'deki gelişmiş ülkelerde aramaları kadınların artan sayılarda göç etmesine dolayısıyla "göçün dişileşmesine" neden olmuştur (Castles, Haas ve Miller 2014, 16). Göçmen kadın emeği özellikle ev işi, çocuk bakımı ve seks işçiliği sektörlerinde tercih edilmiştir (Ehrenreich ve Hochschild 2002, 25).

Ev ve bakım emeği tarihsel olarak kadına ait görüldüğü için fazlasıyla kadınlaşmış bir sektördür; dünyada bu sektörde çalışanların \%80'i kadınlardan oluşmaktadır; göçmen ev işi ve bakım hizmetlerinde çalışanların ise \%73.5'i kadındır ${ }^{8}$. Dünyadaki toplam 67.1 milyon ev çalışanının 11.5 milyonunun (yaklaşık altıda birinin) göçmen olduğu düşünülürse bu meslek küresel olarak belirli etnisiteden, ırk ve sinıftan kadınlar tarafından yapılır hale gelmiştir. Sektörün toplumsal cinsiyet gibi ırkla da ayrıştırılmasını Glenn $(1992,2)$ "yeniden üretim emeğinin ırka dayalı olarak bölünmesi” olarak adlandırır.

Küresel dünyada ev işleri ve bakım hizmetlerinin farklı toplumsal cinsiyet, etnisite ve sınıflardan kişilerin karşılaştı̆̆ yeniden üretildiği bir alan olduğu öne sürülür (Anderson 2000). Bakım işi politiktir (Cox 2010, 113), ancak özel alanda yapıldığı için toplumsal olarak görünmez kılınan bu sektörde çalışan kadınların yaşadıkları toplumsal cinsiyet ve etnisiteye dayalı eşitsizlikler de görünmez hale gelmektedir. Öte yandan bu iş çerçevesinde, alt sınıftan kadınların orta ve üst sınıftan kadınların ev temizliği ve çocuk bakımı işlerini yüklenmesiyle kadınlar arası sınıf farklılıkları da belirgin hale gelmektedir. Ev ve bakım işi, toplumsal cinsiyete, etnisite ve ırka dayalı doğası nedeniyle kadın çalışmaları alanında önemli bir araştırma konusu haline gelmiştir.

Göç eden kadınlar, kendi ev işlerinin yapılması ve çocuklarının bakılması sorumluluğunu aile üyelerine ya da ücretli ev işçilerine bırakmaları ve başka bir ülkede ücret karşılığı çalıştıkları ailenin ev işlerini yapmaları ve çocuklarına bakmaları durumunu Hochschild $(2000,131)$ "küresel bakım zincirleri” olarak Parreñas (2001b, $561)$ ise "uluslararası toplumsal yeniden üretimde iş bölümü” olarak adlandırmaktadır. Sınıfsal olarak ayrıcalıklı kadınların bakım sorumluluklarını kendilerinden daha az ayrıcalıklı Filipinli göçmen kadınlara transfer ederek ev işi ve bakım yüklerini azalttıkları; Filipinler'de kalan kadınların da göç eden kadınların sorumluluklarını hafiflettiği ancak bu iş bölümünün kadınlar arası bir eşitsizlik ilişkisi olduğu öne sürülür (Parreñas, 2010, 1848). Bu makale tam da göçmen yardımcılar ile kadın işverenleri arasındaki bu ev işi ve bakım iş bölümünün yarattığı eşitsizliklerin her iki tarafın annelik deneyimlerine bakarak anlaşılmasını hedefler.

\section{Hong Kong Bağlamı}

Araştırma verilerinin toplandığı Hong Kong, kapitalist piyasa rekabetinin ve sınıf farklılıklarının çok yoğun olarak yaşandığı, ev işi ve bakım hizmetleri alanında göçmen kadın istihdamının çok yaygın olduğu küresel bir Asya şehridir. Sassen (2006, 30) küresel ekonominin kilit fonksiyon ve kaynaklarının bulunduğu, yönetim ve koordinasyon faaliyetlerinin yoğunlaştığı şehirleri "küresel şehir" olarak tanımlar. Küresel şehirlerde yüksek ücretli profesyonellerin talep görmesi onların hayat tarzlarına hizmet etmek üzere çok sayıda düşük ücretli hizmet elemanlarına ve göçmenlere bir talep oluşturur (a.g.e). Küreselleşmenin etkisiyle finans, sigorta, danışmanlık ve ticaret gibi sektörlerde çok sayıda çokuluslu şirket kurulan Hong Kong da bu tanıma uyar. Bir finans merkezi olan ve ulusötesi sermayenin yoğunlaştığı bu küresel şehir, bu şirketlerde çalışmak üzere şehre taşınan expat ailelerine ev sahipliği yapar (Suner:2018).

Göçmen kadınların ev hizmetlerinde istihdamı, özellikle orta sınıf Hong Kong'lu kadınların toplumsal yeniden üretim sorumluluklarını hafifletmek ve iş piyasasına katılmalarına destek olmak amacıyla başlatılmıştır (Wee ve Sim 2005, 176). Göçmen ev çalışanlarının istihdamındaki artışın nedeni devletin çocuk bakımında sağladığı sınırlı hizmet ve sağlanan hizmetin kalitesi hakkındaki olumsuz görüşler olmuştur (Wong 1992, 394). Devlet, çocuk bakım hizmetlerindeki açığını kapatmak için göçmenlerin istihdamını kolaylaştırmış, ödenecek asgari ücreti de düşük düzeylerde belirlemiştir9 ${ }^{9}$ Önceleri ekonomik üst sınıflar için bir ayrıcalık olan ev işi ve bakım çalışanı istihdam etmek orta sınıflar için de erişilebilir hale gelmiştir. Sadece çalışan kadınlar değil çalışmayan kadınlar da kendilerine vakit ayırmak üzere monoton ve sıkıcı görülen ev işlerini göçmen yardımcılarına bırakmışlardır (Constable 2007, 22). Günümüzde de Hong Kong'da Üçüncü Dünya ülkelerinden 
kadınların ev işi ve bakım çalışanları olarak istihdamı oldukça yaygındır. Hong Kong kadınların çocuk bakımı, ev işleri ve yaşlı bakımından sorumlu oldukları (Choi ve Ting, 2009) yani aile içi cinsiyetçi iş bölümünün yaygın olduğu bir toplumdur. $\mathrm{Bu}$ da göçmen kadınlardan alınan yardımın kadınların yükünü hafifletmeye yönelik olduğunu gösterir.

Hong Kong, ülkelerindeki ücretlerin düşüklüğü ve yoksulluk nedeniyle ailelerini geçindirmek ve çocuklarının masraflarını karşılamak amacıyla çocuklarını ve eşlerini geride bırakarak göç eden Filipinli pek çok kadın için önemli bir destinasyon olmuştur (Wee ve Sim 2005, 177). İstatistiki kaynaklara göre Hong Kong'da yaşayan 380.274 göçmen ev ve bakım çalışanının 206.281 'ini (\%54'ünü) Filipinli kadınlar oluşturmaktadır. ${ }^{10} \mathrm{Bu}$ araştırmada, Hong Kong'da ev işi ve bakım çalışanı Filipinli kadınlar, toplumda hem etnik azınlık olmaları hem de ekonomik olarak alt sınıf olmaları; ev işi ve bakım hizmetlerinin toplumsal cinsiyet, etnik köken ve ırka dayalı bir sektör olduğunu çok iyi yansıtmaları, daha kolay erişilebilir olmaları, iyi İngilizce konuşabildikleri için kolay iletişim kurulabilir olmaları ve hem Çinli hem expat aileler tarafından istihdam edilmeleri nedenleriyle tercih edilmiştir.

Hong Kong devleti, orta ve üst sınıftan Çinli ve expat kadınların ev ve bakım işlerinde yüklerinin hafiflemesi, iş hayatı, sosyal hayat ve annelik sorumluluklarını dengelemeleri için göçmen ev işi ve bakım çalışanlarının istihdamını kolaylaştırırken Filipinli kadınların annelik kimliklerini görmezden gelir. Küresel şirketlerde sürdürdükleri kariyerleri için Hong Kong'a taşınan yabancı profesyonellerin ailelerini kendi ülkelerinde bırakmaları söz konusu bile olmazken göçmen kadınların eşlerini ve çocuklarını Hong Kong'a getirmelerinin yani “aile birleşiminin” yasayla önü kapatılmıştır" ${ }^{11}$ Göçmen kadınlar bu şehirde kaç yıl yaşarlarsa yaşasınlar aile birleşiminden faydalanma hakkına sahip olamamaktadırlar.

Hong Kong'da yasaya göre işverenler, göçmen yardımcıları ile iki senelik kontratlar yapmakta; eğer iki yılın sonunda kontrat yenilenirse yardımcılarına evlerine gidip geri dönmeleri için gidiş-dönüş uçak bileti, kontrat yenilenmezse sadece gidiş uçak bileti almakla yükümlüdürler. Filipinler'den göç eden çoğu kadının anne olduğu (Madinaou ve Miller 2011, 458) göz önünde bulundurulduğunda Hong Kong'un göç politikalarının göçmen kadınların annelik deneyimlerini dikkate almadığı görülür. Zira yasa tarafından çocuklarıyla iki senede bir görüşmeleri uygun görülmüştür. Görüştüğüm çoğu ev işi ve bakım çalışanı bilet fiyatlarının yüksek olması nedeniyle kendileri bilet alamadıklarını belirtmiş̧lerdir. Bazıları ise işverenlerinin izin vermesi durumunda özel günlerde (mezuniyet, doğum günü vb.) kendi biletlerini alıp ülkelerine gitmekte çocuklarının yanında olmaktadır. Bazı yardımcılara ise ailelerini ziyaret etmeleri ve çocuklarını görmeleri için işverenleri her sene izin vermekte ve bilet almaktadır. Her iki durumda da çalışanın çocuklarını görme sıklıkları ve bir anlamda annelik deneyimlerinin nasıl şekillendiği işverenin vicdanına kalmaktadır. Çocuklarından ayrı yaşadıklarını hayal dahi edemeyen bazı kadın işverenler, kendilerini yardımcılarının yerine koyar ve onları çocuklarını görmek üzere her sene ülkelerine göndermeye çalışırlar.

\section{Filipinli Ev İşi ve Bakım Çalışanlarının Annelik Deneyimleri}

Küreselleşmeyle birlikte "göçün dişileşmesi" aile yapılarının değişmesine neden olmuş; belirli bir zaman diliminde veya çoğu zaman birbirlerinden ayrı yaşayan ancak birbirlerine bağlılıklarını sürdüren ve ulusal sınırlar ötesinden ortak bir refah ve birlik yaratan "ulusötesi aileler" oluşmuştur (Bryceson ve Vuorela 2002, 3). Hondagneu-Sotelo ve Avila (1997, 548) Amerika'da yaşayan Latin Amerikalı göçmen kadınların annelik pratiklerini göç ile dayatılan zamansal ve mekânsal ayrılıklara uyum sağlayacak şekilde düzenlemelerini "ulusötesi annelik" olarak adlandırırlar. Ulusötesi annelik, kadınların göç ettiklerinde bakım sorumluluklarını nasıl yerine getirecekleri ve çocuklarına bakan kişilerle anneliği nasıl müzakere edecekleri üzerine düşündürür.

Filipinli kadınlar için göç kararı almak her zaman kolay değildir; bu karar çocuklarını geride bırakmak ve onların ihtiyaçlarını sağlamak arasında seçim yapmak gibi ikircikli bir durumu da beraberinde getirir. Söz konusu annenin çocuğunu geride bırakması olunca anneliğin kadınların asli görevi olarak görüldüğ̈̈ geleneksel toplumlarda göç eden annelerin eleştirilmeleri de kaçınılmaz olmaktadır. Oysa göçmen kadınlar göç ederek çocuklarını bırakmazlar sadece çocuklarına sınır ötesinden bakım sağlamanın (Tungohan 2013) ve onlara uzaktan annelik yapmanın (Parreñas 2001b, 361) farklı yollarını bulmaya çalışırlar. Ama annelikleri sürekli mercek altındadır; bir yandan kazandıkları ücretler ile ülke ekonomisine katkı sağladıkları için "yeni ulusal kahramanlar" ilan edilirken (Rodriguez 2010, 84) öte yandan annelerin çocuklarının yanında olması gerektiği düşüncesine dayanan hâkim annelik ideolojilerine göre "kötü anne" ilan edilir ve yerilirler. (Parreñas 2010, 1829) 


\section{Filipinli Ev İşi ve Bakım Çalışanlarının “İyi Anne” Olma Anlayışları}

Çocuklarına uzaktan annelik yapan Filipinli ev işi ve bakım çalışanlarının geleneksel "iyi annelik" anlayışlarını1 ${ }^{12}$ kendi göç deneyimlerine göre nasıl yeniden tanımladıklarını tartışacağım. Araştırma kapsamında Filipinli kadınlar için iyi anne olma hem göç deneyimi çerçevesinde ideal bir annelik anlayışını hem de mevcut annelik deneyimlerini nasıl gördüklerini ortaya koyar.

\section{Kendini Feda Etme}

Fresnoza-Flot (2009, 263) Paris’te yaşayan Filipinli göçmen ev işi ve bakım çalışanlarının "iyi anne” olmayı bulundukları ülkede daha çok çalışma ve aileleri ile birlikte olma arzularını feda etme olarak ifade ettiklerini öne sürer. Benzer şekilde Bocaggni $(2012,265)$ de ulusötesi annelerin anlatılarında çocuklarını geride bırakmayı kendini feda etme, çocuklara yönelik sorumluluk taşıma ve onlara iyi bir gelecek sağlamak üzere bir firsat olarak ifade ettiklerinden söz eder.

Hong Kong'da görüştüğüm Filipinli ev işi ve bakım hizmetleri çalışanlarının tamamı çocuklarına iyi anne olmayı "kendini feda etme" olarak dile getirdiler; çoğu feda ettikleri şeyleri ise çocuklarının büyüdüğünü görme, onlarla birlikte zaman geçirme, özel günlerinde yanlarında olma olarak tarif ettiler.

"3 oğlum okuyor. Kocamın geliri yeterli değil. Ben kendimi feda etmek zorundayım. Mutluluk çocuklarınla olmaksa feda etmek çocuklarım demek... Onlar için zor ama benim için daha zor. Onların büyüdügünü göremiyorum. Onlara iyi geceler diyemiyorum. Kendinizi, sevginizi feda etmeniz gerek. Bu benim ailem, çocuklarım için." (Jane ${ }^{13}$, dört çocuk annesi)

Göçmen kadınlara göre anne olmak demek Filipinler'deki iş firsatlarının azlığı ve yaşadıkları finansal zorluklar nedeniyle çocuklarına iyi bir gelecek sağlamak için göç etmek ve onlarla geçirecekleri bir hayatı feda etmek demektir. Kadınlar kendi hayatlarını iyileştirmek için değil ailelerine daha iyi bir hayat sağlamak için göç ederler (Tyuldum 2015, 62) ve annelik deneyimlerini çocuklarından ayrı geçirdikleri zaman, kaçırdıkları anlar, onlara duydukları özlem ve onlar için daha iyi olacak bir geleceğe olan umut ile özdeşleştirirler. Bir yandan ailelerini geçindiren bir yandan ülke ekonomisine katkı sağlayan bu kadınlar aslında çocuklarından, sevdiklerinden ve ülkelerinden uzak bir ömür geçirerek kendilerini feda ettiklerini düşünürler.

Ancak bu kendini feda etme söylemine karşı temkinli yaklaşılması gerekir zira bu, göçmen kadınlardan bir beklenti haline gelmiştir. Filipin devleti, aileye duyulan hürmet (filial piety) ve kendini feda etme retoriği ile göçmen kadınların saygınlıklarını artırarak onları "yeni ulusal kahramanlar" ilan eder ve kazandıkları ücretleri ailelerini geçindirmek ve ülkelerini kalkındırmak üzere Filipinler’e göndermelerini bekler (Rodriguez 2010, 84). Benzer şekilde Francisco $(2009,129)$ da aile ve ulusa dayalı bir ahlak ekonomisinin kadınların evlerini bırakıp göç etmelerine müsaade ettiğini ve göçmen kadınların da kendilerini feda etmelerinin onlara itibar ve saygınlık kazandıracağını bildiklerini öne sürer. Ama bu ahlak ekonomisi her zaman göçmen kadınların lehine işlemez.

\section{Çocukların İhtiyaçlarının Karşılanması}

Filipinler toplumsal cinsiyet açısından oldukça gelenekseldir; "evin direği” (haligi ng tahanan) olarak görülen erkekler evi geçindirir; "evin ışı̆̆ı olarak görülen" (ilaw ng tahanan) kadınlar ise evi çekip çevirirler (Medina 1992). Ancak kadınların göç ederek evi geçindirmeleri evdeki cinsiyetçi iş bölümünde önemli bir değişikliğe neden olmamış; ev işleri ve geride kalan çocukların bakım sorumluluklarını ailenin diğer kadın üyeleri yüklenmiştir (Parreñas, 2010, 1847).

Frensco-Flot $(2009,256)$ da Fransa'da görüştüğü Filipinli göçmen kadınların "iyi anne” olmayı annelik yükümlülüklerini çocuklarının ekonomik ihtiyaçlarını sağlayarak yerine getirmek olarak düşündüklerini ifade eder. Benzer şekilde Hong Kong'da görüştüğüm göçmen kadınlar da fiziksel olarak çocuklarının yanında olmayışlarını kazandıkları ücretlerden düzenli olarak gönderdikleri para transferleri ile telafi etmeye çalışırlar. Gönderilen transferler ile çocukların gündelik ihtiyaçları karşılanır ve eğitim masrafları ödenir. Çocuklarının geçimi en önemli misyonlarıdır zira göç ile edinilecek maddi kazancın duygulanımsal kayıpların etkisini azaltacağına inanılır (Bocaggni 2012, 265). Çocuklarına hiçbir şey veremeden onların yanlarında olacaklarına uzakta olup ihtiyaçlarını karşılamak ve istediklerini alabilmek onlar için iyi anneliktir. İki çocuk annesi Nadia’nın sözleri de bunu doğrular: 
"Benim için çok acı, çocuğumun doğum gününde hiçbir şey verememek. Maddi olmasa da özel bir şey. $\mathrm{Bu}$ [göç etmek] benim seçimim, anne olarak benim çocuklarımı sevme şeklim. Eğer sen çok yoksul olmana rağmen kalmayı tercih edersen bu da senin seçimindir."

Araştırmaya katılan göçmen kadınların tamamı anneliklerini öncelikle çocuklarının ihtiyaçlarının karşılanması olarak anlamlandırırlar; onlar için anne olarak çektikleri sıkıntıların bir nedeni vardır; o da çocuklarının kendilerine iyi bir gelecek vereceğine inandıkları eğitimi almalarını sağlamaktır. Zira göçmen ev işi ve bakım çalışanları için en büyük yatırım çocuklarının eğitimine yaptıkları yatırımdır (Parreñas 2001a). Görüştüğüm tüm Filipinli kadınlar öncelikle çocuklarına daha iyi bir gelecek sağlamak ve onlara kendilerininkinden farklı bir hayat sunmak amacıyla onların eğitimi için göç ettiklerini belirtirler. Çocuklarından ayrı kalmayı onların gündelik ihtiyaçlarının karşılanması ve iyi bir eğitim almalarının sağlanması ile meşrulaştırırlar.

Öte yandan Parreñas (2010, 1853) göçmen kadınların ailelerini geçindirmelerinin ve ekonomik ihtiyaçları sağlamalarının anne-çocuk ilişkisi kurulması için yeterli olmadığını yakınlığın sürdürülmesi için annelerin daha çok duygusal emek sarfederek çocuklarına sevgilerini uzaktan göstermeleri, duygusal bakım sağlamaları gerektiğini öne sürer. Annelerinin para transferleri çocukların ihtiyaçlarını karşılasa da onların terkedilmişlik hislerini azaltmamaktadır.

Frensco-Flot (2009, 258) Filipinli kadınların çocuklarıyla ve akrabalarıyla aralarındaki duygusal bağları maddi olmayan formlarda da göstermek için, içine pek çok eşya koydukları balikbayan kutuları Filipinler'e gönderdiklerinden söz eder. Hong Kong'da da yüzlerce Filipinli kadın izin günlerinde balikbayan kutularına hediyelik eşya, temizlik ve bakım malzemesi, oyuncak, çikolata, giysi vb. koyar ve ailelerine yollarlar. Bu sayede kadınlar, yokluklarını telafi etmeye, annelik sorumluluklarını yerine getirmeye ve çocuklarıyla aralarındaki yakınlıkları sürdürmeye çalışırlar (a.g.e).

\section{Çocuklarla İletişim Kurma}

Fiziksel birlikteliğin söz konusu olmadığı ulusötesi aile üyeleri ancak iletişim teknolojileri aracılığıyla yürütülen gündelik faaliyetler sayesinde bir ailenin parçası olabilirler (Madianou 2016, 185). Bilgisayar dolayımlı iletişim teknolojilerinin kullanımı ile göçmen Filipinlilerin geride kalan topluluklarında "mevcut olmayan varlığı" (absent presence) sağladıklarından söz edilir (Pertierra 2005, 26).

Uluslararası iletişim teknolojilerinin gelişmesi kadınların uzaktan annelik yapma şekillerini de değiştirmiştir. Göçmen kadınlar iletişim teknolojilerinin anneliklerinin kaçınılmaz bir yönü olduğunu kabul ederler bu sayede ülkeler arası yaptıkları anneliklerinin "gerçek" bir annelik deneyimine dönüştüğünü, kendilerini "tam bir anne" gibi hissettiklerini ifade ederler (Madianou 2012, 290). Ancak Parreñas (2014, 430) Filipinler'in teknolojik alt yapı eksiklikleri, göçmenlerin kaynak yetersizliği ve çalışma koşullarının müsait olmaması nedeniyle bazı göçmenlerin ve ailelerinin bu teknolojilere erişemediğini bu nedenle iletişimin herkes için aynı koşullarda gerçekleşmediğini öne sürer.

Görüştüğüm Filipinli anneler çocuklarıyla hemen her gün telefonla konuştuklarını; çocuklarından uzakta yaşadıkları ve onlarla uzun aralıklarla görüşebildikleri için çocuklarıyla kurdukları iletişimin uzaktan annelik deneyimlerini şekillendiren en önemli unsur olduğunu belirtirler. İletişim teknolojileri sayesinde çocuklarını veya onların birincil bakıcılarını arayıp, çocuklarının ne yediklerini, kaçta uyuduklarını, okula gidip gitmediklerini ve ödevlerini bitirip bitirmediklerini sorduklarını bu sayede onların günlük hayatlarını izlediklerini ve onları kontrol ettiklerini ifade ederler.

Göçmen anneler evlerinde mikro yönetim yapmak ve çocuklarının nasıl yetiştirildikleri üzerinde kontrol sahibi olmak isterler; bu onları güçlendirir (Madianou 2012, 290). Dört çocuk annesi Jane'in sözleri bunu doğrular gibidir:

"Her gün saat 15:30'da eşimi arıyorum ve küçük kızımı okuldan almasını hatırlatıyorum. Buradan yönetmeye çalışıyorum. İşverenime telefonumu gün içerisinde bırakamayacağımı söyledim o benim çocuğumu izleme yöntemim.” 
Madianou ve Miller $(2011,463)$ da gelişen iletişim teknolojileri sayesinde göçmen annelerin "uzaktan yoğun anneliği”" deneyimlediklerini öne sürerler. Öte yandan Parreñas $(2005,333)$ iletişim teknolojilerinin gelişmesine rağmen göçmen kadınların çocuklarıyla "tam” bir yakınlık kuramadıklarını; zira ulusötesi aile üyelerinin fiziksel temasın, varlığın verdiği duygusal güven ve fiziksel yakınlığın verdiği aşinalığa erişemediklerini iddia eder.

\section{Çocuklarla Zaman Geçirme}

Filipin toplumunda hakim olan annelik ideolojisi annelerin çocuklarla birlikte olması gerekliliğini dayattığı için çocuklarından ayrı yaşayan göçmen kadınlar da kendi annelikleri hakkında çelişkili düşüncelere sahiptirler. Kendi annelik deneyimlerine uymasa da anneliği çocuklarının yanında olma üzerinden tanımladıkları için kendilerini iyi anne olarak görmezler. İki oğlunu eşine bırakarak Filipinler'den göç eden Grace, çocukları için göç etmiş olsa da çocuklarıyla zaman geçiremediği için iyi bir anne olmadığını düşünür.

"İyi bir anne miyim bilmiyorum... İyi anne olmanın farklı türleri var gibi. Galiba ben değilim. Çocuklarımla değilim şimdi, ama bunu onlar için yapıyorum.”

Madianou $(2012$, 282) göçmen kadınların çocuklarının ülkelerinde kalmasının ve işlerinin göç ettikleri şehirde olmasının onlarda "vurgulanan ikirciklik" (accentuated ambivalence) durumu yarattığını, anne ve çalışan kimliklerinin kadınları iki farklı yöne doğru çekiştirdiğini öne sürer. Göç eden kadınlar bir yanda çocuklarına olan sevgileri diğer yanda onların geleceği için daha iyi ücretler kazanma firsatları arasında ikircikli bir durumda kalırlar. Oysa göç ederek yaptıkları seçim çocuklarına sevgisizliklerini göstermez aksine bu anneler çocuklarını sevdikleri için ve onların ihtiyaçlarını karşılamak arzusu ile göç ederler. "Bırakan anne seven annedir" ${ }^{14}$ diyen Francisco-Menchavez (2019) de Filipinler'de göç eden kadınlar için bırakmanın sevme ile ilişkili olduğunu (100), artık Filipinli kadınların göçü anneliğin kabul edilebilir bir şekli olarak hatta iyi anneliğin bir yolu olarak normalleştirdiklerini öne sürer (92).

Göç ettikleri için çocuklarından ayrı kalan kadınlar (kendileri için geçerli olmasa da) annelerin çocuklarıyla zaman geçirmelerinin önemine inanırlar. Tek kızını anne ve babasına bırakarak göç eden Linda da bunu şu sözlerle dile getirir:

“Zaman, çocuğuna verebileceğin en güzel şey... Benim kızım büyüyor ve ben onunla değilim. Eğer anneysen zaman en iyisi. Aranızda bağ oluşturur."

\section{Kadın İșverenlerin Annelik Deneyimleri}

1970'lerden beri göçmen yardımcı istihdam edilen Hong Kong'da çocuk bakım sorumluluklarının yabancı ev çalışanlarıyla paylaşılması çocuklu kadınların iş hayatına atılmasında ve ekonomik olarak aktif kalmasında en önemli faktörlerden biri olmuştur. Görüşülen kadın işverenlerin ortak noktası Filipinli yardımcı istihdam etmeleri ve annelik işini onlarla paylaşmalarıdır.

\section{Kadın İşverenlerin “İyi Anne” Olma Anlayışları}

Günümüz toplumlarında yaygın olarak kabul edilen yoğun annelik ideolojisine (intensive mothering) göre çocuk yetiştirmede zaman, maddi kaynak ve enerji sarf edilmeli ve anne asıl bakım sağlayan olmalıdır (Hays 1996, 8). Toplumda benimsenen annelik ideolojileri ücretli işlerde çalışan kadınların da ücretsiz olarak ev işlerini yapan kadınların da annelik deneyimlerinin şekillenmesinde ve "iyi anne" tanımlarının inşa edilmesinde rol oynar. Yoğun annelik ideolojisine göre "iyi annelik" inşaları annelerin çocuk yetiştirmeye yoğunlaşmaları gerektiğini göstermekte ve anne olan kadınlarda çeşitli nedenlerle suçluluk duygusu yaratabilmektedir (Maher ve Saugeres 2007, 6).

Hem çalışan hem çalışmayan annelerden oluşan kadın işveren örneklemine de Filipinli yardımcıların anlatılarıyla olan farklılıkları anlayabilmek için "iyi annelik" anlayışlarını sordum. Farklı cevaplar arasından öne çıkan ve birbirleriyle kesişen üç örüntüden söz etmek mümkün görünmektedir.

\section{Koşulsuz Olarak Sevme ve Güven Verme}

Çocukları koşulsuz olarak sevme, onları sevgi dolu bir ortamda yetiştirme ve onlara güven duygusu verme pek çok kadın işverenin iyi annelik anlatısında karşımıza çıkar. Ruddick $(1980,348)$ annelik işini koruma, fiziksel, 
duygusal ve entelektüel gelişim için yetiştirme ve toplumda kabul görecek iyi insanlar olmaları için eğitme olarak anlatır. Annelik pratikleri sevgi ile başlar; daha önce deneyimlenmemiş yoğun, kafa karıştırıcı, ikircikli ve tatlı bir sevgi (a.g.e). Çalışan bir anne olarak Natalie'nin iyi annelik anlatısı Ruddick'in düşüncelerini doğrular gibidir:

"Onları koşulsuz sevmek, onlara duygusal ve fiziksel olarak bakmak ve kaliteli zaman vermek ve onlara iyi insanlar olmaları için rehberlik etmek.” (Natalie, iki çocuk annesi, Çinli)

Hays $(1996,58)$ de ailelerin çocuk sevgisini ve çocukların ihtiyaçlarını karşılama çabasını yoğun annelik ideolojisinin bir niteliği olarak yorumlar. Tarih boyunca çocuk yetiştirme pratikleri annelik sevgisini yansıtır, günümüzde de pek çok anne çocuk yetiştirme pratiklerini ve ideallerini çocuklarına olan sevgilerinin bir yansıması olarak görürler.

"En önemli şey çocuğunda "güven” duygusu oluşturabilmek. Çocuğun kayıtsız şartsız güvenmeli. Çocuğunun bir sürü şeyi yanlış yapmasını engellersin. Bana yalan söylemesine gerek olmadığını, onu kayıtsız şartsız, koşulsuz seveceğim ve yanında olacağım duygusunu verebilmek en önemlisi bu..." (Melissa, iki çocuk annesi, expat)

Melissa ise iyi anneliği çocuklarında güven duygusu yaratmak olarak görür; sevgi ve güveni ilişkilendirir. Ona göre koşulsuz olarak sevilen çocuklar anneleriyle güven ilişkisi de kuracak ve annelerinin her koşulda onların yanında olacağını bilecektir. Bu nedenle de anneler çocuklarıyla güven üzerine kurulu bir ilişki yaratmayı ve onlara sevildiklerini hissettirmeyi iyi annelik olarak düşünmektedirler.

\section{Rehberlik Etme ve Destek Olmak}

Bir grup anne de iyi anneliği çocuklarına kendi doğrularını bulmaları, kendi potansiyellerine ulaşabilmeleri ve gelecekte iyi bir insan olmaları için rehberlik etmek, çocukları hata yaptıklarında yanında olmak, başarısız olduklarında onlara destek vermek ve tam potansiyellerine ulaşmalarına yardımcı olmak olarak ifade eder.

"Çocuklarımı ruhsal, fiziksel ve finansal olarak desteklemek istiyorum. Ruhsal destek ona "yapabilirsin” demek veya üzgün olduğunda onu rahatlatmak. Onlara rehberlik etmek, öğretmek ancak onlara kendi görüşlerinizi empoze etmemek" (Betty, iki çocuk annesi, Çinli).

Betty’e göre iyi annelik, çocuklarına her şekilde destek olmak ama onları etki altında bırakmadan kendi istekleri doğrultusunda bağımsız karar vermelerini sağlamaktır. Bu sayede kendine güvenen, bağımsız bireyler yetiştirebilecektir. Çocuğun hayatını tamamen yönlendirmek yerine tökezlediğinde yanında olmanın çocuğun kendine olan güvenini arttıracağına inanır.

"İyi bir anne, daha iyi bir insan olması ve tam potansiyeline ulaşması için çocuğuna rehberlik eden, ona öğreten biridir. Düştüğü zaman yanında olmak... Her zaman güven duygusunu sağlamak... Ve hayatta ne olursa olsun her şeyin düzeleceğini söyleyerek onu rahatlatmak. Orada olacağım ve onları hatalarıyla kabul edeceğim ve başarısızlıklarında, hayal kırıklıklarında ve reddedilmelerinde onlara destek olacağım.” (Vanessa, iki çocuk annesi, Çinli)

Vanessa bunları söylerken biraz da kendini ikna etmek ister gibidir zira üç yaşındaki kızı girmesini istedikleri okula ilk yıl girememiş ve Vanessa büyük hayal kırıklığı yaşamıştır.

\section{Farklı Deneyimlere İmkân Să̆lama}

Görüş̧üğüm kadın işverenlerin bazıları da iyi anneliği çocuklarına kendi yeteneklerini keşfetmeleri amacıyla farklı deneyimler için imkân sağlama olarak ifade etmiştir. Bu anneler çocuklarını ne kadar çok farklı deneyim ile tanıştırırlarsa çocuklarının ileride yapmayı isteyecekleri faaliyetleri o kadar kolay seçeceklerini ve daha başarılı olacaklarını düşünmektedirler. Çıkan bu temanın da yoğun annelik ideolojisiyle ilgili olduğunu düşünüyorum zira anneler tüm imkanlarını çocuklarının farklı deneyimler yaşamaları için kullanmaktadırlar. 


\begin{abstract}
"Çocuklarıma keşfetmeleri için olanaklar sunuyorum. Tutkuları her ne ise... Eğer öğrenmek istiyorlarsa elbette öğrenmeleri için bir yol bulurum. Kendileri keşfedebilirler. Anne olarak kendi yollarını bulmaları için olabildiğince farklı şeylere maruz bırakıyorum ama yollarını çizmiyorum." (Kate, 2 çocuk annesi, Çinli)
\end{abstract}

Hays (1996) orta sınıf annelerin çocuklarıın gerekli kültürel sermayeyi almalarını sağlayarak onları gelecekteki sınıfsal konumları için hazırladıklarını ve çocuklarına bu lüksleri sunamayan veya bunları iyi çocuk yetiştirmenin temel prensiplerinden görmeyen annelere göre kendi sınıf statülerini gösterdiklerini öne sürer. Hong Kong'daki anneler de eğitim sisteminin rekabete dayalı olduğu bu küresel şehirde çocuklarının geride kalmamaları için onları farklı deneyimlerle tanıştırmak isterler.

"Onları farklı şeylere maruz bırakmalısınız. Jimnastik, müzik, kültür, insanlar, dil. Oğlum beyin ve hafıza hareketlendirmek için olan "Shichida" kursuna gidiyor." (Betty, 2 çocuk annesi, Çinli).

\title{
Annelik Deneyimlerinin Farklılı̆̆ ve İlişsiselliği
}

Hong Kong'da yaşayan Filipinli ev işi ve bakım çalışanlarının ve kadın işverenlerin annelik deneyimleri sınıf, etnisite ve göç politikaları kesişiminde farklılıklar gösterir. Filipinli ev işi ve bakım çalışanları anneliklerini ulusötesi annelik (Hondagneu -Sotelo ve Avila 1997, 548) ideolojisi çerçevesinde çocuklarına uzaktan annelik yapmak üzerine inşa ederler. Anlatılarında göç etme kararlarını ve çocuklarından ayrı kalmak zorunda olmalarını nasıl meşrulaştırdıklarını veya yokluklarını nasıl telafi ettiklerini dile getirirler. Çocuklarıyla birlikte yaşayan kadın işverenler ise anneliklerini yoğun annelik ideolojisi (Hays 1996) çerçevesinde inşa ederler. Ancak bir farkla... Görüştüğüm tüm kadın işverenler bu idealleri istihdam ettikleri göçmen yardımcılarından aldıkları destek ile gerçekleştirirler. Anneler çalışsa da çalışmasa da göçmen yardımcıları çocuklarını gerektiğinde okula götürür ve okuldan alır, çoğunlukla okul sonrası kurslara veya oyun gruplarına götürürler.

Annelik deneyimlerindeki farklılığın ilk boyutu sınıfsaldır. Filipinli ev işi ve bakım çalışanları ülkelerinde yaşadıkları yoksulluk ve yoksunluk nedeniyle ailelerini geçindirmek amacıyla çocuklarından ayrı kalmak pahasına göç etme kararı alırken Hong Kong'da yaşayan kadın işverenler onların emeğini satın alarak ev işi ve çocuk bakımında istedikleri standartlara ulaşır, kariyerlerine odaklanabilir veya kendilerine vakit ayırabilirler.

Lareau (2003) toplumsal sınıfın annelik pratiklerini etkilediğini ve orta sınıf kadınların çocuklarının yeteneklerinin geliştirilmesi için eğitimlerini ve okul sonrası faaliyetlerini yakın bir şekilde süpervize ettiklerini öne sürer. Hong Kong’ta görüştüğüm orta ve üst sınıf annelerin tamamı çocuklarının yetiştirilmesinde özel öğretmenlerden destek almalarını sağlamakta ve çocuklarını okul sonrası kurslara göndermektedirler. Bu, çocuk yetiştirme pratiklerinin ailelerin sınıfsal konumlarına bağlı olarak sahip oldukları kaynaklar ile yakından ilişkili olduğunu da gösterir (Gillies 2005, 842). Zira akademik başarılarını artırmak için çocukları farklı kurslara yazdırmak ve onları farklı deneyimlerle tanıştırmak önemli bir finansal kaynak ayırmayı da gerektirir. Öte yandan görüştüğüm göçmen kadınların neredeyse tamamı çocuklarını devlet okuluna gönderirler. Ancak hiçbiri çocuklarını okul sonrası kurslara gönderdiklerinden veya özel öğretmenlerden ders aldıklarından bahsetmemiştir. Yeoh ve Huang $(2010,32)$ eğitim başarısının sosyo-ekonomik yükselmeyi ifade ettiği küresel dünyada kadınların "iyi annelik" ideallerinin artık sadece çocukları yetiştirmek olmadı̆̆ını; annelerin aynı zamanda birer eğitim temsilcisine dönüştüklerini ve çocukların eğitiminin annelik pratiklerinin temelini oluşturduğunu öne sürerler. Hong Kong'da yaşayan kadın işverenler için eğitimin çocuk yetiştirmenin en önemli unsuru olduğunu söyleyebiliriz. Zira anneler için okul seçmek, bekleme listelerine girmek, portföy oluşturmak ve mülakatlara hazırlanmak oldukça önemli meseleler haline gelmiștir.

Annelik deneyimlerindeki farklılığın ikinci boyutu da etnik kökene ilişkindir. Küresel dünyada ev işi ve bakım sektöründe belirli etnik kökenden kadınların daha fazla tercih ediliyor olması bu kadınları göçe teşvik etmekte ve çocuklarına uzaktan annelik yapmaya mecbur bırakmaktadır. Bu da ulusötesi anneliğin çoğunlukla belirli etnik kökenden kadınlar tarafından deneyimlenmesine neden olmaktadır. Göçmen yardımcı istihdam eden kadın işverenler ise Hong Kong'da yaşayan expat ailelerde olduğu gibi ülke değiştirseler dahi ailelerinden veya çocuklarından ayrılmak durumunda kalmamakta, bu mağduriyeti yaşamamaktadırlar. 
Annelik deneyimlerindeki farklılığın üçüncü boyutu ise göç politikalarına ilişkindir. Cheng $(2003,136)$ küreselleşme çağında göç etmek zorunda olan pek çok kadın için en büyük sorunun göç politikalarıyla çocuklarına geleneksel anlamda (fiziksel olarak yanlarında olarak) annelik yapamamaları ve "annelik yapma haklarından" mahrum kalmaları olduğunu ileri sürer. Hong Kong'da göçmen kadınlar sadece "kısmi vatandaşlık" (Parreñas 2001a, 18) haklarından yararlandıkları için annelik deneyimleri devletin göç politikaları tarafından kısıtlanır. Öte yandan orta ve üst sınıf kadın işverenler göçmen yardımcılarının desteğiyle çocuklarına pek çok imkân sunabilmekte, yoğun annelik ideolojisine uygun olarak belirledikleri ideal annelik modelini uzaktan kontrol ederek uygulayabilmektedirler.

Filipinli ev işi ve bakım çalışanları ailelerini geçindirmek için göç etmiş olsalar da çocuklarının yanında olmadıkları için yerilir, kötü anne olmakla suçlanırlarken (Parreñas 2010, 1829) kadın işverenler onlardan aldıkları yardımlarla iyi anne olma ideallerine bir adım daha yaklaşırlar. Kadın işverenler çocuklarıyla güven ve sevgi ilişkisi üzerine anneliklerini inșa ederken göçmen yardımcıların çocukları ekonomik olarak ihtiyaçları karşılansa da terkedilmişlik ve ihmal edilmişlik duygusu yaşadıklarını dile getirirler (Parreñas 2010, 1851).

Her iki gruptan kadının annelik deneyimleri farklı olduğu kadar ilişkiseldir. Kadın işverenler yardımcılarıyla anneliklerini müzakere ederler ve "iyi annelik" algılarına zarar verdiğini düşündükleri için tüm annelik sorumluluklarını yardımcılarına delege etmekten rahatsızlık duyarlar (Cheng 2006, 204). Görüştüğüm kadın işverenlerin çoğu çocuklarıyla kaliteli zaman geçirmek istediklerini dile getirirler ve önemli gördükleri işleri kendileri yaparken daha önemsiz gördükleri işleri ise yardımcılarına bırakırlar. Göçmen kadınlar çocuklarından uzakta yaşarken kadın işverenler çocuklarıyla kaliteli zaman geçirirler.

Öte yandan görüştüğüm Filipinli göçmen kadınlar anlatılarında kadın işverenleriyle kurdukları iyi ilişkinin ve işverenlerinin, onların çocuklarından ayrı yaşamalarına, gösterdikleri empatinin annelikleri açısından öneminin altını çizerler. Zira bu sayede çocuklarını görmek üzere Filipinler'e daha sık gitmeleri mümkün olmakta, evde müsait oldukları zamanlarda telefonla çocuklarıyla daha rahat konuşabilmekte ve ailelerini geçindirmek için huzurla çalışabilmektedirler.

\section{Sonuç}

$\mathrm{Bu}$ makalede Hong Kong'da yaşayan Filipinli ev işi ve bakım çalışanlarının ve kadın işverenlerinin annelik deneyimlerini “iyi annelik" anlayışları üzerinden tartıștım. Araştırmanın bulgularına göre farklı toplumsal konumlardan olan bu kadınların annelik deneyimleri sınıf, etnisite ve göç politikaları kesişıminde farklılaşmaktadır. Göçmen Filipinli kadınlar anneliklerini ulusötesi annelik ideolojisi çerçevesinde çocuklarına uzaktan annelik yaparak; kadın işverenler ise yoğun annelik ideolojisi çerçevesinde çocuklarının yetiştirilmesi için fazlasıyla kaynak ayırarak inşa ederler. Farklı toplumsal konumlardaki bu kadınların anneliklerinin ortak yanı çocuklarının eğitimine verdikleri önemdir.

Her ikisi de çalışmak (veya çalışan eşi takip etmek) için aynı şehre taşınan göçmen kadınlarla expat kadınlara uygulanan göç politikaları arasındaki farklılıklar kadınlar arasındaki eşitsizlikleri arttırmaktadır. Ayrıcalıklı toplumsal konumda olan kadınlar ellerindeki kaynaklar ve aldıkları yardım ile iyi annelik ideallerini farklı şekilde kurgular, önceliklerini farklı şekilde belirlerler. Onların ev işlerini yapan ve çocuklarına bakan göçmen kadınların ise iyi anne olma idealleri ve öncelikleri tamamen farklıdır zira çocuklarına uzaktan annelik yaparlar. Göçmen kadınların anneliklerini göç deneyimleri, onların anneliklerini yadsıyan göç politikaları ve işverenleriyle kurdukları ilişkiler dönüştürür. Çocuklarına yakın olmadan da annelik yapmanın farklı yollarını bulurlar. Kadın işverenlerin annelik deneyimleri ise Hong Kong'daki rekabetçi çocuk yetiştirme pratikleri, eğitime verilen önem ve göçmen yardımcılarından aldıkları destek ile dönüşür. 
${ }^{1}$ Yazar kitabın altıncı bölümde Filipinli ev işi ve bakım çalışanlarının ve Tayvanlı kadın işverenlerin annelik deneyimlerini tartışır. ${ }^{2}$ Expatriate kelimesinin kısaltılmış1 olan expat gönüllü göçmenliği ifade etmek için kullanılır. “Expat'lar sunulan farklı çalışma imkanları nedeniyle başka ülkelerde yaşamayı tercih eden kişilerdir. Kavramın Türkçe'de tam bir karşılığı olmamakla birlikte yabancı bir ülkede çalışan/iş yapan şirket yöneticileri, beyaz yakalı çalışanlar ve orta sınıf serbest meslek erbabını" kapsar. (Suner:2018: 54)

${ }^{3}$ Etnik bir grup olan Filipinli kadınlar göç ettikleri için benzer annelik deneyimlerini paylaşırlar; anlatıları da bunu gösterir. Çinli kadınlar ise Hong Konglu, Anakara Çinli ve Tayvanlı kadınlar olarak etnik bir grup olarak düşünülebilir. Expat kadınlar ise etnik bir grup değildir ama sınıfsal bir kategori olarak alınmıştır.

${ }^{4}$ Hong Kong'da ev işi ve bakım çalışanlarına İngilizce "helper" denmektedir. Bu nedenle makalede "yardımcı" ve ev işi ve bakım çalışanları ifadelerini değişimli olarak kullandım.

${ }^{5}$ Çeviri yazara aittir.

${ }^{6}$ Çeviri yazara aittir.

${ }^{7}$ Bir derinlemesine görüşme Türkçe yapılmıştır.

${ }^{8}$ http://www.unwomen.org/en/digital-library/multimedia/2016/9/infographic-migrant-domestic-workers sayfasindan 17 Mayis 2020 tarihinde erişilmiştir.

${ }^{9}$ Hong Kong'un kişi başına GSMH'nın Aralık 2019 itibariyle 48.718 ABD\$'dir. Göçmen ev işi ve bakım çalışanlarının aldıkları asgari ücret ise 4.630 HKD (593 ABD\$)'dir. Bunun üzerine 1.121 HKD (143 ABD\$) yiyecek ödeneği verilmesi veya yardımcının ailenin yiyeceklerini paylaşması zorunludur. https://www.ceicdata.com/en/indicator/hong-kong/gdp-per-capita sayfasından $17 \mathrm{May1s}$ 2020 tarihinde erişilmiştir. https://www.gov.hk/en/residents/employment/recruitment/foreigndomestichelper.htm

${ }^{10} \mathrm{https}: / /$ www.censtatd.gov.hk/hkstat/sub/gender/labour_force/ sayfasından (Foreign Domestic Helpers by Nationality and Sex) 17 Mayıs 2020 tarihinde erişilmiştir.

${ }^{11}$ https://www.immd.gov.hk/eng/services/visas/immigration-entry-guideline.html sayfasından (No.32) 17 Mayıs 2020 tarihinde erişilmiştir.

${ }^{12}$ Çocuklarından uzakta yaşayan göçmen kadınlara ve çocuklarıyla birlikte yaşayan kadın işverenlere farklı koşullarda nasıl "iyi anne" olmaya çalıştıklarını anlamak için "iyi anneliğin ne olduğu sorusunu yönelttim.

${ }^{13}$ Tüm katılımcılar için takma isim kullanılmıştır.

${ }^{14}$ Yazar tarafindan çevrilmiştir.

\section{Kaynakça}

Anderson, Bridget. Doing the Dirty Work? The Global Politics of Domestic Labour, (New York:Zed Books.2000).

Anthias, Floya. "Hierarchies of social location, class and intersectionality: Towards a translocational frame"; International Sociology 28, No.1 (2012):121-138.

Badinter, Elisabeth. Kadınlık mı Annelik mi? (İstanbul: İletişim Yayınları, 2011).

Boccagni Paolo. "Practising Motherhood at a Distance: Retention and Loss in Ecuadorian Transnational Families", Journal of Ethnic and Migration Studies, 38, No.2 (2012):261-277.

Bourdieu, Pierre. Distinction. A Social Critique of the Judgement of Taste (London: Routledge. 1994, [1984]).

Bourdieu, Pierre. (1986), "The forms of capital”. Handbook of Theory and Research for the Sociology of Education ed. Richardson John G. (New York: Greenwood Press, 1986), 241-258.

Castles, Stephen, Haas, de Hein ve Miller Mark, J. The Age of Migration, (New York: The Guilford Press, 2014).

Cheng, Shu-Ju. Ada, "Right to Mothering: Motherhood as a Transborder Concern in the Age of Globalization" Journal of the Association for Research on Mothering, Vol.6, No.1 (2003):135-144.

Cheng, Shu-Ju. Ada., Serving the Household and the Nation: Filipina Domestics and the Politics of Identity in Taiwan. (MD: Lexington Books, 2006).

Choi ve Ting, “A Gender Perspective on Families in Hong Kong”, ed. Cheung Fanny and Holroyd Eleanor, Mainstreaming Gender in Hong Kong Society. (Hong Kong: Chinese University Press, 2009).

Collins, Hills, Patricia, "Shifting the Center, Race, Class and Feminist Theories about Motherhood", ed. Glenn, Evelyn, Nakano, Chang, Grace and Forcey, R. Linda Mothering: Ideology, Experience, and Agency. (New York: Routledge: 1994): 45-65.

Cox, Rosie. "Some Problems and Possibilities of Caring" Ethics, Place and Environment 13, No.2, (2010): 130.

Constable, Nicole. Maid to Order in Hong Kong, (Londra: Cornell University Press: 2007). 
Crenshaw, Kimberle., "Mapping the Margins: Intersectionality, Identity Politics and Violence Against Women of Colour", Standford Law Review 43, 6, (1991):1241-1299.

DiQuinzio, Patricie. “Mothering and Feminism” Maternal Theory: Essential Readings ed. O'Reilly Andrea (Canada: Demeter Press: 2007). (New York: Routledge: 1999):542-555.

Donovan, Josephine. Feminist Teori (İstanbul: İletişim Yayınları: 1997).

Ehrenreich, Barbara ve Hochschild, Arlie. "Introduction", Global woman: Nannies, maids, and sex workers in the new economy, ed. Ehrenreich, B. \& Hochschild Arlie, (New York: Henry Holt and Company: 2002):21-33.

Fresnoza-Flot, Asuncion. "Migration Status and Transnational Mothering: The Case of Filipino Migrants in France" Global Networks 9, 2, (2009): 252-270.

Francisco, Valerie. "Moral Mismatch: Narratives of Migration from Immigrant Filipino Women in New York City and the Philippine State", Philippine Sociological Review 57, (2009): 105-135.

Francisco-Menchavez, Valerie. "A Mother Who Leaves is A Mother Who Loves: Labor Migration as Part of the Filipina Life Course and Motherhood”, Journal of Asian American Studies 22, No.1 (2019): 85-102.

Gillies, Val. "Raising the Meritocracy: Parenting and The Individualisation of Social Class", Sociology 39, No.5 (2005): 835-853.

Gilligan, Carol. “In a Different Voice” (Massachusetts: Harvard University Press: 1982).

Glenn Evelyn, Nakano. "From Servitude to Service Work: Historical Continuities in the Racial Division of Paid Reproductive Labour", Signs 18, No. 1 (1992):1-43.

Glenn, Evelyn. Nakano. (1994). "Social Constructions of Mothering: A Thematic Overview," Mothering: Ideology, Experience, and Agency. ed. Evelyn. Nakano Chang, Grace and Forcey, R. Linda (New York: Routledge:1994):1-29.

Harding, Sandra. “Introduction” The Standpoint Theory Reader, (New York: Routledge: 2004):1-13.

Hays, Sharon. The Cultural Contradictions of Motherhood, (New Haven, CT: Yale University Press:1996).

Hochschild, Arlie. Russell. "Global care chains and emotional surplus value," On the edge: Living with Global Capitalism ed. Hutton, Will. \& Giddens, Anthony. (London: Jonathan Cape: 2000):130-146.

Hondagneu-Sotelo, Pierette. ve Avila, Ernestine. "I am here, but I am there": the meanings of Latina transnational motherhood" Gender and Society 11, 5 (1997):548-71.

Lareau, Anette., Unequal Childhoods: Class, Race and Family Life, (Berkeley: University of California Press: 2011).

Madianou, Mirca. "Migration and the Accentuated Ambivalence of Motherhood: The Role of ICTs in Filipino Transnational Families" Global Networks 12, No.3, (2012): 277-295.

Madianou, Mirca. “Ambient co-presence: transnational family practices in polymedia environments” Global Networks 16, 2 (2016): 183-201.

Madianou, Mirca. ve Miller, Daniel. "Mobile Phone Parenting: Reconfiguring Relationships between Filipina Migrant Mothers and Their Left-Behind Children", New Media \& Society 13, No.3, (2011):457-470.

Maher, JaneMaree. ve Saugeres, Lisa. "To be or not to be a mother? Women negotiating cultural representations of mothering", Journal of Sociology 43, No.1, (2007):5-21.

Medina, Belen, T.G. The Filipino Family: A Text with Selected Readings (Quezon City: University of the Philippines Press: 1992).

O’Reilly, Andrea. “Feminist Mothering” Maternal Theory: Essential Readings ed. O’Reilly Andrea (Canada: Demeter Press: 2007):792-821. 
Parreñas, Rachel.S. Servants of Globalization: Women, migration and domestic work. (Stanford, CA: Stanford University Press: 2001a [2014]).

Parreñas, Rachel.S., "Mothering from a Distance: Emotions, Gender, and Intergenerational Relations in Filipino Transnational Families" Feminist Studies, 27, No.2 (2001b):361-39.

Parreñas, Rachel.S. "Long Distance Intimacy: Class, Gender and Intergenerational Relations between Mothers and Children in Filipino Transnational Families" Global Networks 5, No.4 (2005):317-336.

Parrenas, Rachel.S. "Transnational Mothering: A Source of Gender Conflicts in The Family" North Carolina Law Review 88, (2010), 1825-1856.

Parrenas, Rachel.S. "The intimate labour of transnational communication", Families, Relationships and Societies, 3, No.3 (2014):425-42.

Pertierra, Raul. “Mobile Phones, Identity and Discursive Intimacy”, Human Technology 1, No.1 (2005):23-44.

Rich, Adrienne. Of Woman Born: Motherhood as Experience and Institution, (London: Virago: 1976).

Rodriguez, Robin, Magalit., "Migrants for Export: How the Philippine State Brokers Labour to the World". (Minneapolis: University of Minnesota Press: 2010).

Ruddick, Sarah. "Maternal Thinking”, Feminist Studies, 6, No. 2, (1980):342-367.

Sassen, Saskia. "Global Cities and Survival Circuits" ed. Zimmerman Mary, Litt, Jacquelyn. Bose, Christine. Global Dimension of Gender and Carework, (CA: Stanford University Press:2006), 30-36.

Sancar, Serpil., Türk Modernleşmesinin Cinsiyeti, (İstanbul, İletişim Yayınları: 2012).

Scott, Joan.W, “The Evidence of Experience”, Critical Inquiry, 17, No.4: (1991):773-797.

Skeggs, Beverly. Formations of Class and Gender, (London: Sage:1997).

Suner, Asuman. Hong Kong İstanbul, (İstanbul: Metis Yayınları:2018).

Tungohan, Ethel. "Reconceptualizing Motherhood, Reconceptualizing Resistance", International Feminist Journal of Politics 15, No.1, (2013):39-57.

Tyuldum, Guri. "Motherhood, Agency and Sacrifice in Narratives on Female Migration for Care Work", Sociology 49, No. 1 (2015):56-71.

Wee, Vivienne ve Sim, Amy. "Hong Kong as a Destination for Migrant Domestic Workers" Asian Women as Transnational Domestic Workers, ed. Huang, Shirlena, Yeoh, Brenda. ve Abdul Rahman, Noor (2005): 175209.

Wong, C. K. 'Economic Growth and Welfare Provision: The Case of Child Day Care in Hong Kong', International Social Work No.35, (1992): 389-404.

Yeoh, Brenda. ve Huang, Shirlena. "Mothers on the move: Children's education and transnational mobility in globalcity Singapore" ed. Chavkin, Wendy. ve Maher, JaneMaree. The Globalization of Motherhood: Deconstruction and Reconstruction of Biology and Care, (New York: Routledge.2010): 31-54 